\title{
TRANSMISSION NETWORK MANAGEMENT OF N-1 CONTINGENCIES IN THE 110 KV ATLÁNTICO NETWORK WITH BESS THROUGH LINEAR OPTIMIZATION: CASE STUDY
}

\author{
EDWIN RIVAS TRUJILLO, OSCAR DANILO MONTOYA \& CESAR LEONARDO TRUJILLO
}

\author{
Universidad Distrital Francisco José de Caldas, Bogotá, Colombia
}

\begin{abstract}
This article presents an implementation of Battery Energy Storage Systems (BESS) for a transmission network. Methods: A linear optimization model in AMPL+CPLEX is used to establish the minimum sizes of batteries that can solve overloads in lines and transformers for $\mathrm{N}-1$ contingencies of the $110 \mathrm{kV}$ Atlántico network. Findings: The best solutions are sought in possible generation-demand scenarios of said network based on criteria such as minimum battery size and lower numbers of 'non-feasible' cases related to $\mathrm{N}-1$ contingency's overloads. Improvement: The locations of batteries proposed by UPME, XM, and Quanta are tested as well as three proposed locations.

KEYWORDS: AMPL, BESS, Contingencies, DIgSILENT-PowerFactory, DC flow
\end{abstract}

Received: Nov 08, 2020; Accepted: Nov 28, 2020; Published: Dec 04, 2020; Paper Id.: IJMPERDDEC20205

\section{INTRODUCTION}

Energy storage systems (ESS) arise from the need to balance the fluctuations in electric energy supplies, guaranteeing the reliability, security, and harnessing of non-conventional renewable energy sources [1]. For applications with short charging times, the ESS can control the frequency, contribute to the network power quality and solve stability problems. In the case of applications with longer duration (energy supply for several hours), ESS can take over tracking the loads and managing the network congestion through re-dispatch, among other tasks [2].

ESS have a multifunctional role in electric supply networks, integrating with renewable energy applications, transmission, and distribution networks and auxiliary services (voltage and frequency regulation, or spinning reserve). Some applications related to transmission networks include transmission capacity release, congestion management, peak-load relief in the network, black start, reliability in distribution systems, frequency response, and spinning reserve capacity.

In Colombia, network issues in the $110 \mathrm{kV}$ Atlántico network are caused by a deficit in the capacity of the transmission lines and transformers of 110 and $34,5 \mathrm{kV}$ when facing N-1 contingencies. Common problems are related to losing a transformer or line [3], restrictions in the generation values for thermic central of Tebsa and Termoflores as well as delays in the expansion projects defined by UPME in the Caribbean Region in Colombia [4].

The case study focuses on the city of Barranquilla, referring to the Transmission Capacity Release due to congestion problems in N-1 contingency transmission networks. However, it can also happen in normal system conditions when the peak-load leads to overloads labeled as $\mathrm{N}-0$ congestion.

Figure 1 shows the flow of the AC load in $110 \mathrm{kV}$ Atlántico networks carried out in the DigSILENT 2017 
Power Factory, against contingencies of the Union transformer $110 / 34,5 \mathrm{kV}$.

The Mining and Energetic Planning Unit (by its acronym in Spanish UPME) stated the 2015-2029 Expansion Plan which considers using BESS to respond to contingencies in the Atlántico network, thus avoiding restrictions in the generation dispatches of Flores and Tebsa power plants for a secure operation of the Atlántico networks.

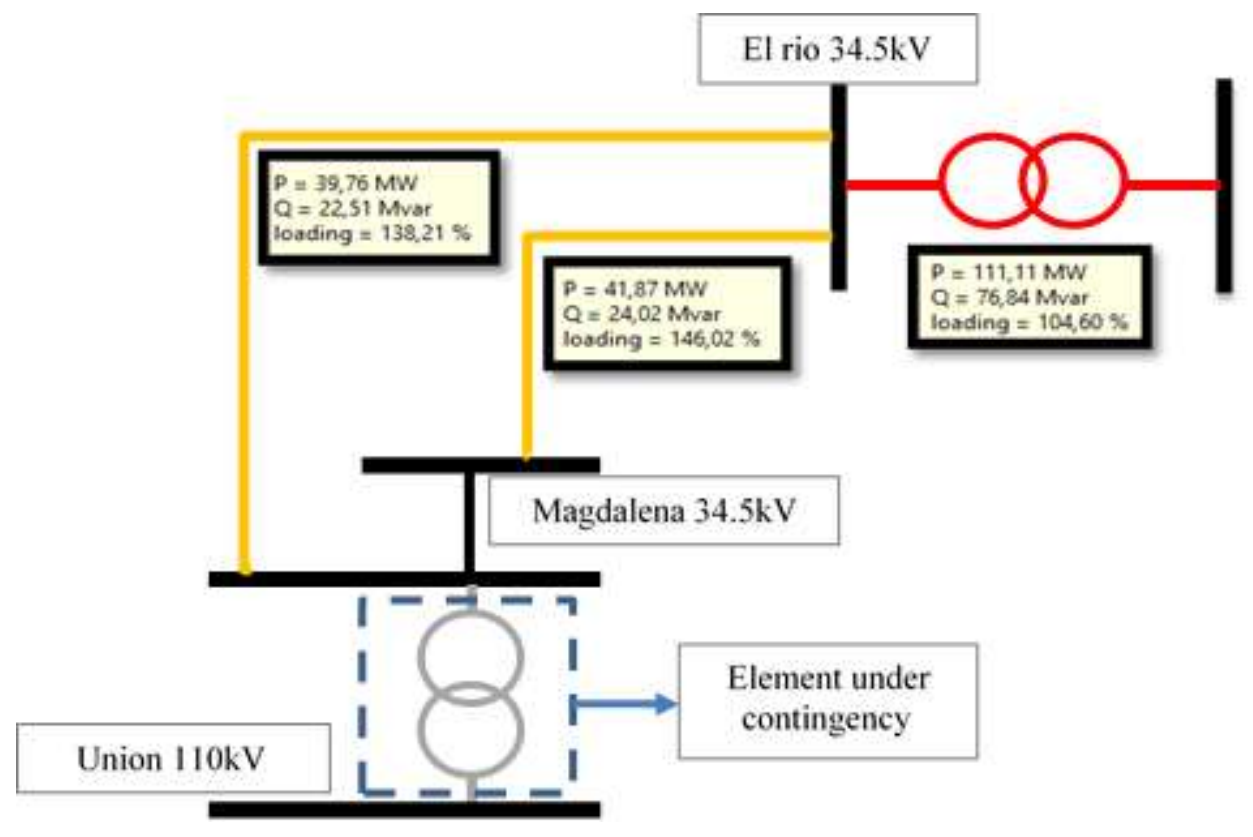

Figure 1: Overloads in lines and transformers of the Atlántico STR during contingency in the Unión 110/34,5 kV transformer.

\section{CONTEXT}

Energy storage systems (ESS) are considered temporary solutions that can relieve saturation and electrical problems [5] In contrast to the new transmission lines, the ESS are much easier to install and have already shown some economic benefits for the postponement of the transmission. [5]

BESS is expected to play an important role as network assets in the near future. The main benefits are with the operation of the network (Voltage control, management and restoration of energy flow) and with the energy market.

There are two main advantages to using BESS. First, BESSs can serve as support for lines that suffer saturation in a reduced percentage of their operating time without the need to invest in new expensive lines. Second, while the transmission network is being reinforced with new lines and generators, BESSs can improve the performance of stressed energy systems or systems with intermittent and unpredictable sources. [5]

By implementing BESSs, welfare increases because these systems can store energy when prices are low and provide it to the network when they are high

- Net social welfare depends largely on the cost, the amount of energy that can be stored and the power of these systems.

- In some cases, the inclusion of a storage system allows the construction of some lines to be delayed. This is a key issue, since the construction of the line takes a long time and generates many problems, especially with regard to 
environmental impact. [5]

\section{THE BATTERIES}

The batteries are made of stacked cells where chemical energy is converted into electrical energy and vice versa. The desired battery voltage as well as the current levels are obtained by electrically connecting the cells in series and in parallel. The batteries are classified in terms of their power and power capabilities. For most types of batteries, the power and energy capabilities are not independent and are set during battery design. Some of the other important characteristics of a battery are efficiency, lifespan (indicated in terms of number of cycles), operating temperature, discharge depth (batteries are generally not completely discharged and discharge depth is refers to the extent to which they are discharged), self-discharge (some batteries cannot retain their electrical capacity when stored on a shelf and the self-discharge represents the discharge speed) and energy density. [6]

BESSs have been designed to achieve multifunction to directly improve the reliability and operation of the power system and the others are indirect applications (usually in the form of adding new features / providing greater capabilities to custom power devices, SVC, STATCOM, etc.) [6]

The implementation of a linear optimization model using the AMPL+CPLEX software is proposed for different scenarios of generation-demand of the STR Atlántico of $110 \mathrm{kV}$ against N-1 contingencies, with the purpose of obtaining the adequate sizes of BESS with initially predetermined locations.

The solutions offered by UPME, the ISA subsidiary XM and Quanta Technology are compared as well as the solutions proposed to observe the effectiveness of a BESS for solving overloads due to $\mathrm{N}-1$ contingencies. Figure 2 shows the single-line diagram for the Atlántico network in voltage levels: $220 \mathrm{kV}, 110 \mathrm{kV}$, and $34.5 \mathrm{kV}$.

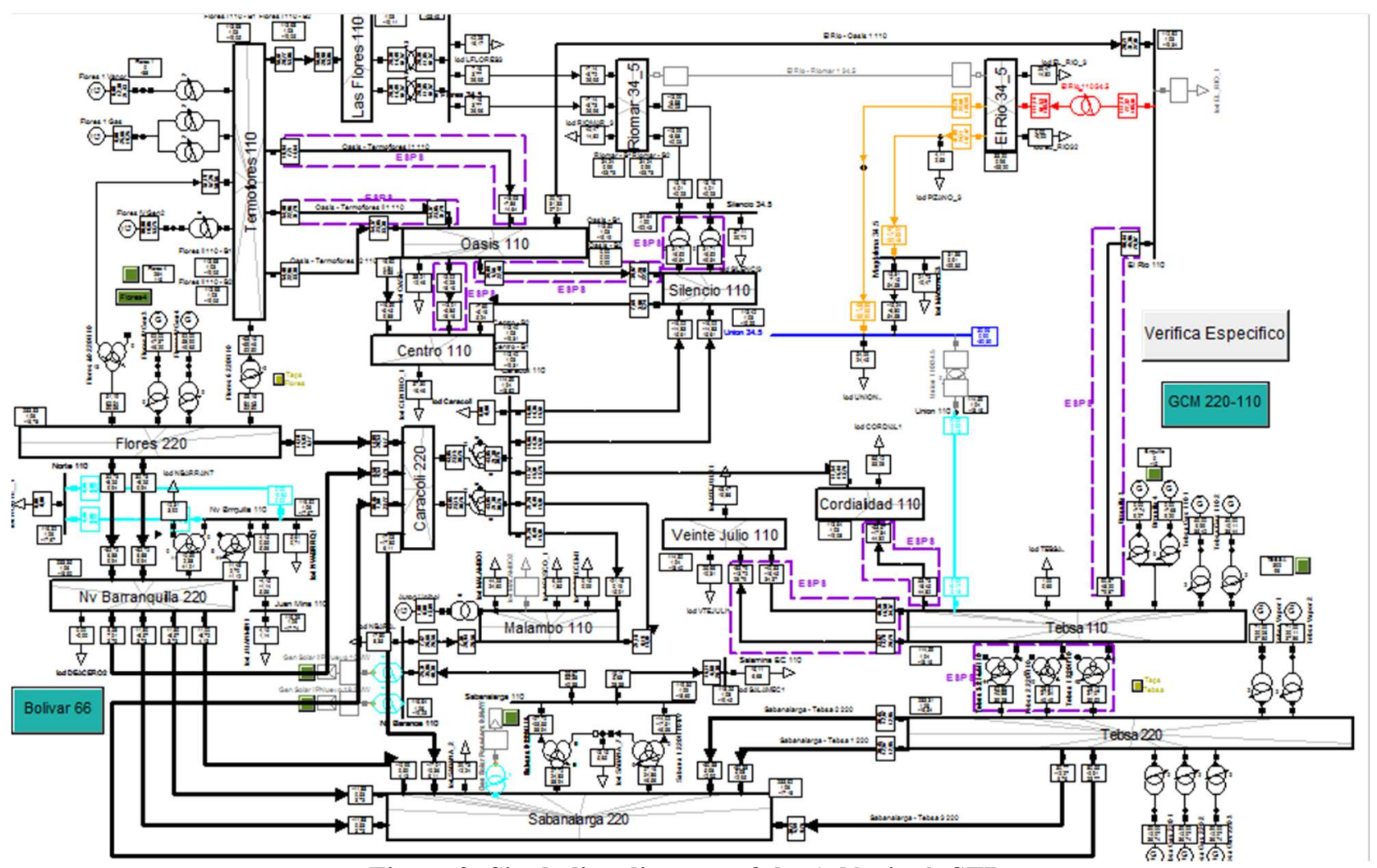

Figure 2: Single-line diagram of the Atlántico's STR. 


\section{OPTIMIZATION MODEL}

Energy storage only operates when a network contingency occurs, allowing the system to return to a secure operation condition where there are no overloads in the $110 \mathrm{kV}$ lines and transformers, making sure that supplementary protection schemes are not required.

This operational schema has the potential to save considerable costs in areas where the construction of new lines is not-feasible3. Energy storage eliminates restrictive contingencies for power generation. Figure 3 shows that Battery Energy Storage Systems (BESS) can lead to no overloads in the network during N-1 contingency events (failure or output of lines and transformers) thereby supplying the remaining energy until it is re-dispatched in power stations of the system.
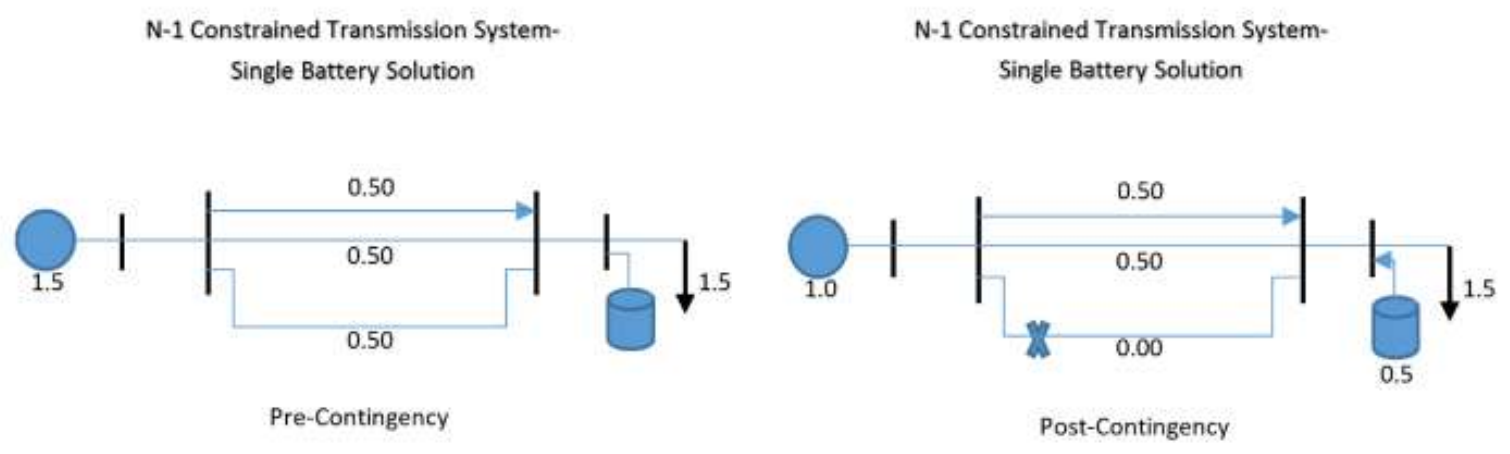

Figure 3: Energy storage for $\mathrm{N}-1$ contingencies [5].

For the application scenario of the Transmission Capacity Release in the Atlántico, a linear optimization was established through DC flow and developed in AMPL+CPLEX in order to determine adequate battery sizes for the solution of overloads against contingencies. For this model, the following variables are considered: angles of the voltages in 'theta' bars, injection of battery power in 'pbat' network contingencies, power flows in the 'fzer' branches and generation of slack 'pslack' (Savannah station - 230 kV).

The AMPL model defines some electric parameters that do not change when they execute the optimization program. Its target function consists in minimizing the required size (p.u.) for batteries, considering all the locations assigned for BESS. Furthermore, some restrictions and electric parameters are included, such as the generation of all nodes except for the slack, as well as the bars' demand, the reactance of branches, the normal capacities (FMAX) and the contingency capabilities (FMXC) of all branches which does not change in the resolution of the linear optimization problem. Figure 4 shows a flow diagram for the AMPL optimization model. 


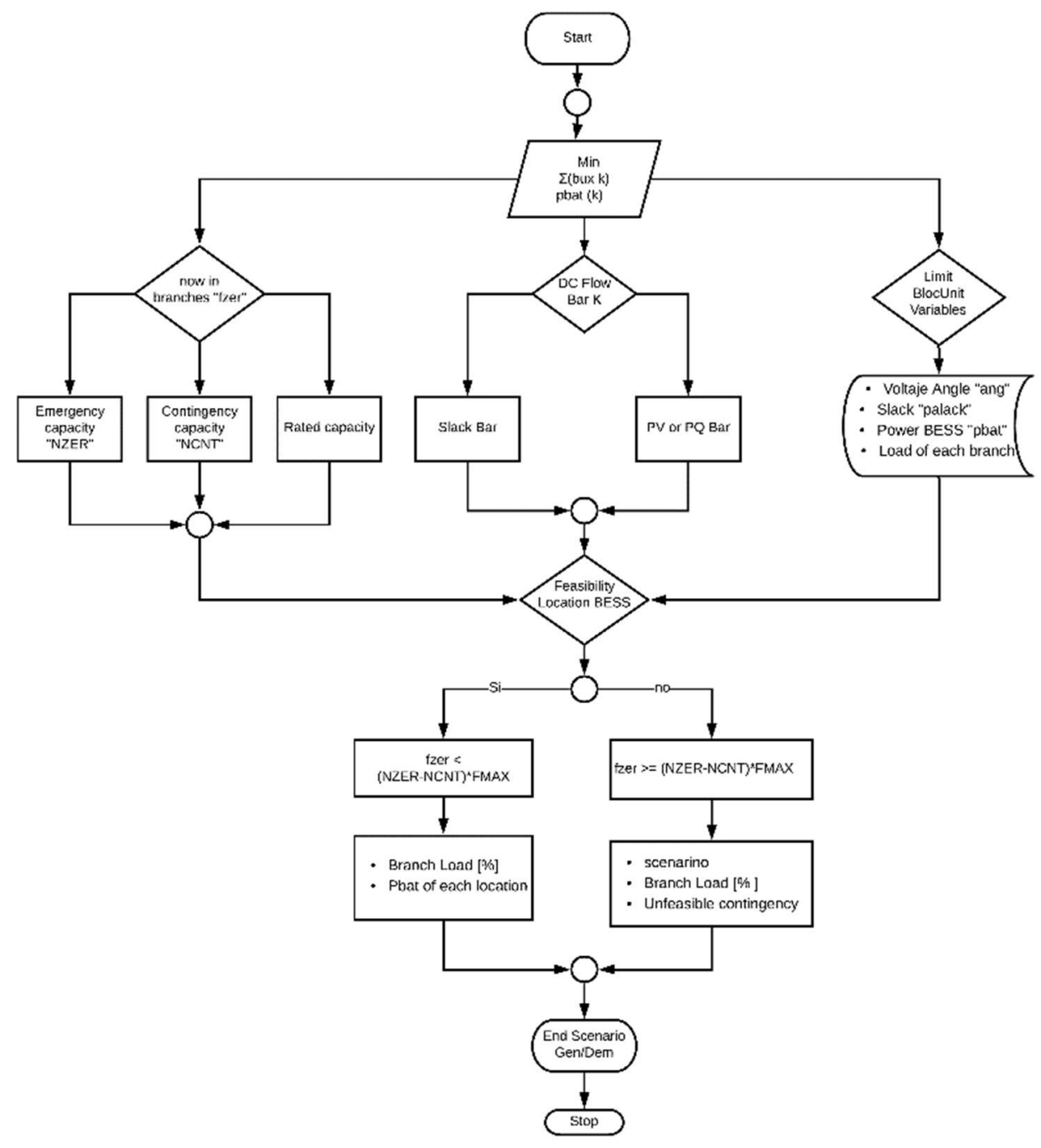

Figure 4: Flow diagram for the AMPL optimization model

For the AMPL model, the DC flow of the first law of Kirchhoff is proposed depending on whether the bus is Slack, $\mathrm{PV}$ or PQ and considering the generation and demand in branches as well as the 'Pbat' power of the installed batteries, always respecting the maximum flows per branch. The power flow per branch is calculated in lines and transformers, considering the difference between the limits of NZER emergency capacity and the admissible overload in contingency (NCNT). A non-feasible case is considered when the capacity in contingency (FMXC) is surpassed in one branch, represented through the relation (NZER-NCNT)*FMAX. Finally, the limits of the electric variables are also included: voltage angles, pslack generation, and power injected by batteries.

Figure 2 shows a single-line diagram for the Atlántico region, with a total of 82 branches without including power generation transformers, radial lines or elements that were not represented in the database of the Colombian interconnected system. In addition, there are 51 lines and transformers with ST connection, 12 STN lines and 53 buses with a slack bus in the $220 \mathrm{kV}$ Sabanalarga station.

\section{METHODOLOGY}

This optimization model seeks to confirm the effectiveness of BESS as a solution for overloads under different N-1 
contingency events in the Atlántico network in 2019, simulating 1.860 cases (15 generation scenarios, two scenarios of maximum and minimum demand, and 63 contingencies) for various locations of BESS in the $110 \mathrm{kV}$ and $34.5 \mathrm{kV}$ substations. The following considerations are adopted for the presentation of the results of the AMPL model. In each combination, the DC load flow is used to assess if there are violations of the emergency limits for a branch of flows. A non-feasible case occurs when one or more limits are violated. Fixed alternatives of battery location are evaluated and the model minimizes the power in MW injected by the batteries. Physical variables related to the space have not been considered in the substations, and the unavailability of batteries is not evaluated.

\section{RESULTS}

The scenario of the Atlántico network in 2019 under different generation/demand cases is proposed in order to identify the best locations for BESS. The chosen source of information (configuration, impedances, demands, etc.) is the database of the national interconnected system for the second semester of 2017. It was provided by XM [7].

Table 1: Generation scenarios to be executed in AMPL+CPLEX [7]

\begin{tabular}{|c|c|c|c|c|c|c|c|c|c|c|c|c|c|c|c|c|c|}
\hline Generator & $\begin{array}{c}\text { GEN } \\
\text { MA } \\
\mathrm{X}\end{array}$ & $\begin{array}{c}\text { GE } \\
\mathrm{N} \\
\mathrm{MI} \\
\mathrm{N}\end{array}$ & $\begin{array}{c}\text { Es } \\
\text { c } \\
1\end{array}$ & $\begin{array}{c}\text { Es } \\
\text { c } \\
2\end{array}$ & $\begin{array}{c}\text { Es } \\
\mathrm{c} \\
3\end{array}$ & $\begin{array}{l}\text { Es } \\
\text { c } 4\end{array}$ & $\begin{array}{c}\text { Esc } \\
5\end{array}$ & $\begin{array}{c}\text { Es } \\
\text { c } \\
6\end{array}$ & $\begin{array}{c}\text { Es } \\
\text { c } \\
7\end{array}$ & $\begin{array}{c}\text { Es } \\
\text { c } \\
8\end{array}$ & $\begin{array}{c}\text { Es } \\
\text { c } \\
9\end{array}$ & $\begin{array}{c}\text { Esc } \\
10\end{array}$ & $\begin{array}{c}\text { Esc } \\
11\end{array}$ & $\begin{array}{c}\text { Esc } \\
12\end{array}$ & $\begin{array}{c}\text { Es } \\
\text { c } \\
13\end{array}$ & $\begin{array}{c}\text { Esc } \\
14\end{array}$ & $\begin{array}{c}\text { Esc } \\
15\end{array}$ \\
\hline Unibol_13.2 & 1.1 & 0 & 0 & 0 & 0 & 0 & 0 & 0 & 0 & 0 & 0 & 0 & 0 & 1.1 & 0 & 0 & 0 \\
\hline$\underset{8}{\text { Flores_G1_13. }}$ & 108 & 44 & 0 & 44 & 76 & $\begin{array}{c}10 \\
8\end{array}$ & 44 & 76 & $\begin{array}{c}10 \\
8\end{array}$ & 44 & 76 & 108 & 108 & 108 & $\begin{array}{c}10 \\
8 \\
\end{array}$ & 0 & 0 \\
\hline$\underset{8}{\text { Flores_S1_13. }}$ & 52 & 21 & 0 & 0 & 0 & 0 & 21 & 37 & 52 & 0 & 0 & 0 & 0 & 52 & 52 & 0 & 0 \\
\hline $\begin{array}{c}\text { Flores_G2_13. } \\
\end{array}$ & 106 & 36 & 0 & 0 & 0 & 0 & 0 & 0 & 0 & 36 & 71 & 0 & 106 & 106 & $\begin{array}{c}10 \\
6 \\
\end{array}$ & 0 & 0 \\
\hline Flores_G3_18 & 172 & 92 & 0 & 0 & 0 & 0 & 0 & 0 & 0 & 92 & $\begin{array}{c}13 \\
2 \\
\end{array}$ & 0 & 172 & 172 & $\begin{array}{c}17 \\
2 \\
\end{array}$ & 0 & 0 \\
\hline Flores_G4_18 & 172 & 92 & 0 & 0 & 0 & 0 & 0 & 0 & 0 & 92 & $\begin{array}{c}13 \\
2 \\
\end{array}$ & 0 & 172 & 172 & $\begin{array}{c}17 \\
2 \\
\end{array}$ & 0 & 0 \\
\hline $\begin{array}{c}\text { Tebsa_Gas_11 } \\
013.8 \_1\end{array}$ & 92 & 50 & 0 & 50 & 71 & 92 & 50 & 71 & 92 & 50 & 71 & 92 & 92 & 92 & 0 & 92 & 92 \\
\hline $\begin{array}{c}\text { Tebsa_Gas_11 } \\
013.8 \_2\end{array}$ & 92 & 50 & 0 & 50 & 71 & 92 & 50 & 71 & 92 & 50 & 71 & 92 & 92 & 92 & 0 & 92 & 92 \\
\hline $\begin{array}{c}\text { Tebsa_Gas_22 } \\
013.8 \_1\end{array}$ & 92.2 & 50 & 0 & 50 & 71 & $\begin{array}{c}92 . \\
2 \\
\end{array}$ & 50 & 71 & 92 & 50 & 71 & $\begin{array}{c}92 . \\
2\end{array}$ & $\begin{array}{c}92 . \\
2 \\
\end{array}$ & $\begin{array}{c}92 . \\
2 \\
\end{array}$ & 0 & $\begin{array}{c}92 . \\
2 \\
\end{array}$ & $\begin{array}{c}92 . \\
2\end{array}$ \\
\hline $\begin{array}{c}\text { Tebsa_Gas_22 } \\
013.8 \_2\end{array}$ & 92.2 & 50 & 0 & 50 & 71 & $\begin{array}{c}92 . \\
2 \\
\end{array}$ & 50 & 71 & 92 & 50 & 71 & $\begin{array}{c}92 . \\
2 \\
\end{array}$ & $\begin{array}{c}92 . \\
2\end{array}$ & $\begin{array}{c}92 . \\
2 \\
\end{array}$ & 0 & $\begin{array}{c}92 . \\
2 \\
\end{array}$ & $\begin{array}{c}92 . \\
2\end{array}$ \\
\hline $\begin{array}{c}\text { Tebsa_Gas_22 } \\
013.8 \_3\end{array}$ & 92.2 & 50 & 0 & 50 & 71 & $\begin{array}{c}92 . \\
2 \\
\end{array}$ & 50 & 71 & 92 & 50 & 71 & $\begin{array}{c}92 . \\
2\end{array}$ & $\begin{array}{c}92 . \\
2\end{array}$ & $\begin{array}{c}92 . \\
2\end{array}$ & 0 & $\begin{array}{c}92 . \\
2 \\
\end{array}$ & $\begin{array}{c}92 . \\
2\end{array}$ \\
\hline $\begin{array}{c}\text { Tebsa_Vapor_ } \\
18 \_1\end{array}$ & $\begin{array}{c}165 . \\
2\end{array}$ & 0 & 0 & 0 & 0 & 0 & 0 & 82 & $\begin{array}{c}16 \\
5\end{array}$ & 0 & 0 & 0 & 0 & 165 & 0 & $\begin{array}{c}165 \\
.2\end{array}$ & $\begin{array}{c}165 \\
.2\end{array}$ \\
\hline $\begin{array}{c}\text { Tebsa_Vapor_ } \\
18 \_2\end{array}$ & $\begin{array}{c}165 . \\
2\end{array}$ & 0 & 0 & 0 & 0 & 0 & 0 & 82 & $\begin{array}{c}16 \\
5 \\
\end{array}$ & 0 & 0 & 0 & 0 & 165 & 0 & $\begin{array}{c}165 \\
.2 \\
\end{array}$ & $\begin{array}{c}165 \\
.2 \\
\end{array}$ \\
\hline $\begin{array}{c}\text { Brrquilla_13.8 } \\
3\end{array}$ & 64 & 33 & 0 & 0 & 0 & 0 & 0 & 0 & 0 & 0 & 0 & 0 & 0 & 64 & 0 & 0 & 64 \\
\hline $\begin{array}{c}\text { Brrquilla_13.8 } \\
4\end{array}$ & 63 & 33 & 0 & 0 & 0 & 0 & 0 & 0 & 0 & 0 & 0 & 0 & 0 & 63 & 0 & 0 & 63 \\
\hline $\begin{array}{c}\text { Solar_I_PNue } \\
\text { vo } \\
\text { LV_0.69kV } \\
\end{array}$ & 20 & 0 & 0 & 0 & 0 & 0 & 0 & 0 & 0 & 0 & 0 & 0 & 0 & 20 & 0 & 0 & 0 \\
\hline $\begin{array}{c}\text { Solar_II_PNue } \\
\text { vo }\end{array}$ & 10 & 0 & 0 & 0 & 0 & 0 & 0 & 0 & 0 & 0 & 0 & 0 & 0 & 10 & 0 & 0 & 0 \\
\hline
\end{tabular}



Network with Bess through Linear Optimization: Case Study

\begin{tabular}{|c|c|c|c|c|c|c|c|c|c|c|c|c|c|c|c|c|c|}
\hline LV_0.69kV & & & & & & & & & & & & & & & & & \\
\hline $\begin{array}{l}\text { Solar_Poneder } \\
\text { a LV_0.69kV }\end{array}$ & 10 & 0 & 0 & 0 & 0 & 0 & 0 & 0 & 0 & 0 & 0 & 0 & 0 & 10 & 0 & 0 & 0 \\
\hline $\begin{array}{c}\text { Sabanalarga } \\
220 \mathrm{kV} \text { (Slack) }\end{array}$ & 1000 & $\begin{array}{c}- \\
100 \\
0\end{array}$ & 0 & 0 & 0 & 0 & 0 & 0 & 0 & 0 & 0 & 0 & 0 & 0 & 0 & 0 & 0 \\
\hline Total & $\begin{array}{c}2569 \\
.1\end{array}$ & - & 0 & $\begin{array}{c}29 \\
4\end{array}$ & $\begin{array}{c}43 \\
1\end{array}$ & $\begin{array}{c}56 \\
9\end{array}$ & $\begin{array}{c}31 \\
5\end{array}$ & $\begin{array}{c}63 \\
2\end{array}$ & $\begin{array}{c}95 \\
1\end{array}$ & $\begin{array}{c}51 \\
4\end{array}$ & $\begin{array}{c}76 \\
6\end{array}$ & $\begin{array}{c}568 \\
.6\end{array}$ & $\begin{array}{c}101 \\
9\end{array}$ & $\begin{array}{c}156 \\
9\end{array}$ & $\begin{array}{c}61 \\
0\end{array}$ & $\begin{array}{c}791 \\
.4\end{array}$ & $\begin{array}{c}918 \\
.4\end{array}$ \\
\hline
\end{tabular}

The existing unbalance between load and generation is assumed by the slack node (Sabanalarga $220 \mathrm{kV}$ ).

TABLE 2 describes different demand scenarios in Atlántico. The highest demand for 2019 is detected at 3 pm or P15 according to the XM data, while the lowest demand is used in the P07 period or 7 am, where all data have a base of Sbase $=100$ MVA.

Several simulations are carried out to study the operation of the model with different locations for the BESS. The results obtained for the five options considered in the model, according to the generation-demand scenarios, are:

- UPME: Unión 34,5 kV and Ríomar 34,5 kV.

- Quanta: Veinte Julio $110 \mathrm{kV}$, Malambo $110 \mathrm{kV}$ and Centro $110 \mathrm{kV}$.

- $\quad \mathrm{XM}$ : Oasis $110 \mathrm{kV}$ and Veinte Julio $110 \mathrm{kV}$.

- $\quad$ 1:3 batteries: Magdalena 34,5 kV, Unión 34,5 kV and El Río 34,5 kV.

- 2:6 batteries: Las Flores 34,5 kV, Silencio 34,5 kV, Unión 34,5 kV, El Rio 34,5 kV, Centro 110 kV and Ríomar $34,5 \mathrm{kV}$.

- $\quad 3: 3$ batteries: Las Flores 34,5 kV, Unión 34,5 kV and Ríomar 34,5 kV.

Table 2: Demand scenarios P15 y P07 to run in AMPL+CPLEX (p.u. base 100 MVA).

\begin{tabular}{|l|l|l|l|}
\hline \multicolumn{1}{|c|}{ Load } & \multicolumn{1}{|c|}{ Bar } & P15 (p.u.) & P07 (p.u.) \\
\hline lod ACESCO_1 & Nv_Baranoa_110 & 0,24 & 0 \\
\hline lod CENTRO_1 & Centro_110 & 0,6 & 0,35 \\
\hline lod CORDIAL1 & Cordialidad_110 & 0,66 & 0,59 \\
\hline lod EL_RIO_3 & El_Rio_34_5 & 0,56 & 0,3 \\
\hline lod JUANMIN1 & Juan_Mina_110 & 0,06 & 0,04 \\
\hline lod LFLORES3 & Las_Flores_34.5 & 0,46 & 0,37 \\
\hline lod MAGDALE3 & Magdalena_34.5 & 0,22 & 0,18 \\
\hline lod MALAMBO1 & Malambo_110 & 0,49 & 0,4 \\
\hline lod NBARANO1 & Nv_Baranoa_110 & 0,18 & 0,2 \\
\hline
\end{tabular}




\begin{tabular}{|l|l|l|l|}
\hline lod NBARRAN7 & Nv_Brrquilla_13.8 & 0,11 & 0,09 \\
\hline lod NVABRRQ1 & Nv_Brrquilla_110 & 0,24 & 0,18 \\
\hline lod OASIS_1 & Oasis_110 & 0,77 & 0,4 \\
\hline lod PIZANO_3 & Triplex Pizano 34.5 & 0,04 & 0 \\
\hline lod RÍOMAR_3 & Ríomar_34_5 & 0,67 & 0,37 \\
\hline lod SABANA_2 & Sabanalarga_220 & 0,19 & 0,21 \\
\hline lod SABANA_7 & Nv_Brrquilla_110 & 0,13 & 0 \\
\hline lod SALAMEC1 & Salamina_EC_110 & 0,15 & 0,15 \\
\hline lod SILENCI3 & Silencio_34.5 & 0,51 & 0,35 \\
\hline lod TEBSA_1 & Tebsa_110 & 0,03 & 0,04 \\
\hline lod UNIÓN_3 & Unión_34.5 & 0,58 & 0,46 \\
\hline lod VTEJUL21 & Veinte_Julio_110 & 0,69 & 0,62 \\
\hline lod VTEJULI1 & Veinte_Julio_110 & 0,27 & 0 \\
\hline Total & & 7.23 & 5,1 \\
\hline
\end{tabular}

The AMPL model reveals that the cases are non-feasible, indicating that for 1860 cases the overloads are not solved for N-1 contingencies, in spite of the installation of BESS. The resulting cases are the product between the number of generation scenarios, the number of demand cases and the number of performed contingencies. The AMPL model has the maximum power injected by the BESS in each $\mathrm{I} / \mathrm{O}$ assigned for the optimization program.

TABLE 3 presents the sizes of BESS for different locations and the total of non-feasible cases.

Table 3: Results of the AMPL model for different locations: Non-feasible cases and powers of BESS

\begin{tabular}{|c|c|c|c|c|c|c|c|}
\hline Battery & $\begin{array}{l}\text { Witho } \\
\text { ut } \\
\text { batteri } \\
\text { es }\end{array}$ & $\begin{array}{l}\text { Location } \\
\text { UPME } \\
\text { (p.u.) }\end{array}$ & $\begin{array}{l}\text { Location } \\
\text { Quanta } \\
\text { (p.u.) }\end{array}$ & $\begin{array}{l}\text { Location } \\
\text { XM (p.u.) }\end{array}$ & $\begin{array}{l}\text { Location } \\
1 \text { (p.u.) }\end{array}$ & $\begin{array}{l}\text { Location } \\
2 \text { (p.u.) }\end{array}$ & $\begin{array}{l}\text { Location } 3 \\
\text { (p.u.) }\end{array}$ \\
\hline Unión $34,5 \mathrm{kV}$ & & 0 & & & 0,68 & 0,53 & 1 \\
\hline Ríomar 34,5 kV & & 0,3 & & & & 0,91 & 0 \\
\hline $\begin{array}{l}\text { Las Flores 34,5 } \\
\mathrm{kV}\end{array}$ & & & & & & 1 & 1 \\
\hline El Río $34,5 \mathrm{kV}$ & & & & & 1 & 0 & \\
\hline $\begin{array}{l}\text { Magdalena 34,5 } \\
\mathrm{kV}\end{array}$ & & & & & 0,71 & & \\
\hline Silencio $34,5 \mathrm{kV}$ & & & & & & 0 & \\
\hline Centro $110 \mathrm{kV}$ & & & 0,2 & & & 1 & \\
\hline $\begin{array}{l}\text { Veinte Julio } 110 \\
\mathrm{kV}\end{array}$ & & & 0 & 0,15 & & & \\
\hline $\begin{array}{l}\text { Malambo } 110 \\
\mathrm{kV}\end{array}$ & & & 0,17 & & & & \\
\hline
\end{tabular}



Network with Bess through Linear Optimization: Case Study

\begin{tabular}{|l|l|l|l|l|l|l|l|}
\hline Oasis $110 \mathrm{kV}$ & & & & 0,4 & & & \\
\hline $\begin{array}{l}\text { Non-feasible } \\
\text { cases }\end{array}$ & 325 & 217 & 270 & 261 & 181 & 0 & 34 \\
\hline
\end{tabular}

Based on the results presented in TABLE 3, including the STR+STN contingencies, it is determined that without batteries there are 325 non-feasible cases. The UPME proposal is more effective than the Quanta proposal since it manages to reduce to 217 non-feasible cases in comparison to 270 from Quanta and 261 from XM. In all combinations, the most used batteries to solve contingencies are Las Flores $34,5 \mathrm{kV}$ (twice) and Unión $34,5 \mathrm{kV}$ (four times), where the best option is Location 3, achieving up to 34 non-feasible cases. Figure 5 summarizes for each studied location the number of non-feasible cases in lines and transformers through the installation of BESS. Location 3 has the lowest number of non-feasible cases in transmission networks with a capacity of 200 MW in BESS.

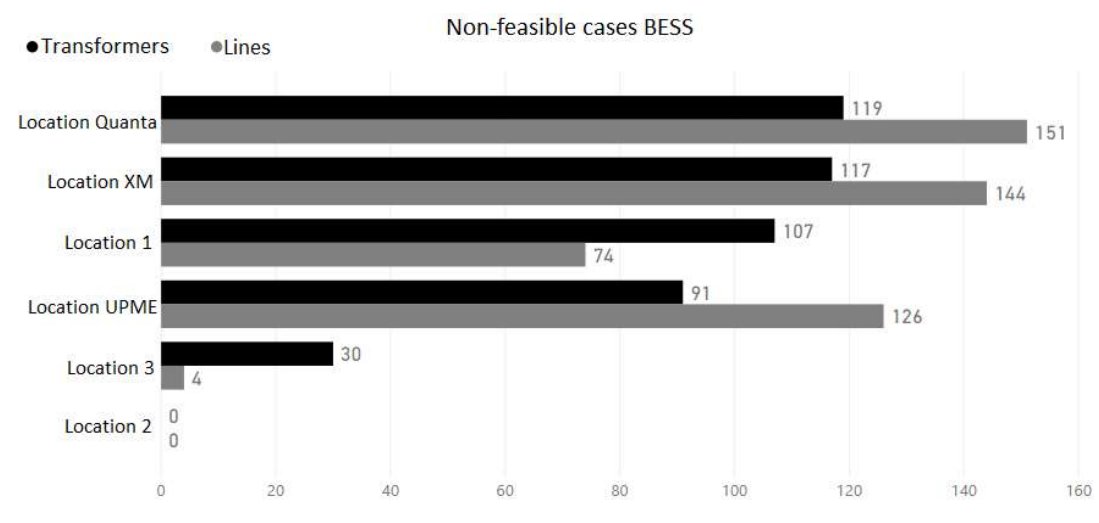

Figure 5: Non-feasible cases for BESS locations.

When the capacity of BESS is reduced in Location 3 to $120 \mathrm{MW}$, there is an increase in the number of non-feasible cases in lines and transformers. The lower installed capacities of BESS are, the higher is the number of non-feasible cases in networks against N-1 contingencies. Figure 6 shows a comparative view between the cases of UPME and Location 3 with capacities of 120 and $60 \mathrm{MW}$ in BESS.

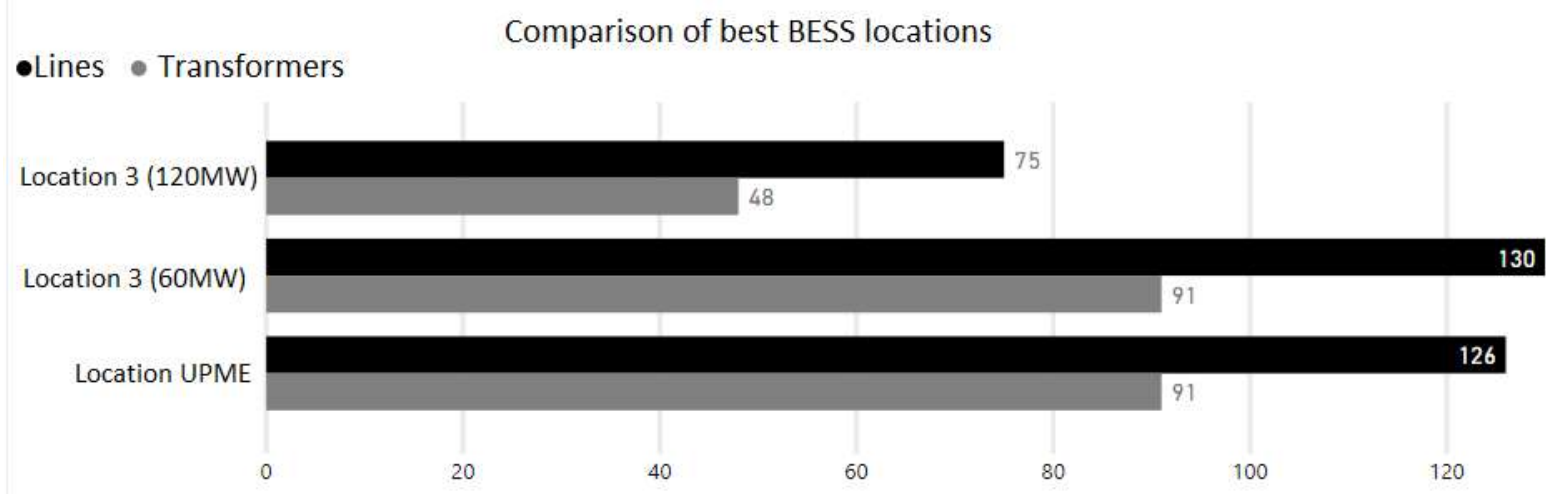

Figure 6: Comparison between the best BESS locations.

When the capacity of batteries is reduced to $60 \mathrm{MW}$ in Location 3, then it has the same effect that solution UPME in the Atlántico network, revealing that under certain contingencies about $344 \mathrm{MW}$ (Location 2) are needed to guarantee a solution for the network. The most critical contingencies are El Río 110/34,5 kV, Tebsa-Unión $110 \mathrm{kV}$, Unión 110/34,5 kV, Transformers in Las Flores 110/34,5 kV and Las Flores-Termoflores $110 \mathrm{kV}$. 
For certain dispatches, there are chargeability issues under N-1 contingencies. The elements showing overload in these cases are El Río-Tebsa $110 \mathrm{kV}$, Flores 6 220/110 kV, Lines Oasis-Termoflores $110 \mathrm{kV}$ and Transformers Tebsa 220/110 kV and Flores 10 220/110 kV.

In TABLE 4 the results are corroborated in DigSILENT Power Factory 2017 (AC flow) for different contingencies, using the best location of the batteries (Location 2 with 0.6 p.u. in Las Flores and Unión 34,5 kV). All contingencies are carried out for the scenario Generation 15, demand P07.

Table 4: Contingencies in DigSILENT Power Factory 2017, elements with chargeability over $100 \%$.

Batteries in Las Flores and Unión $34,5 \mathrm{kV}$ of 0,6 p.u.

\begin{tabular}{|c|c|c|c|c|}
\hline Branch & $\begin{array}{lr}\text { Charge } & \text { without } \\
\text { batteries } & \text { DigSILENT } \\
{[\%]} & \\
\end{array}$ & $\begin{array}{l}\text { Charge with batteries } \\
\text { DigSILENT [\%] }\end{array}$ & $\begin{array}{lr}\begin{array}{l}\text { Charge } \\
\text { batteries }\end{array} & \begin{array}{r}\text { with } \\
\text { AMPL } \\
{[\%]}\end{array} \\
\end{array}$ & Contingency \\
\hline $\begin{array}{l}\text { El Rio - Tebsa } 1 \\
110 \mathrm{kV}\end{array}$ & 138,38 & 101,58 & Does not converge & $\begin{array}{l}\text { Tebsa - Unión } 1110 \\
\mathrm{kV}\end{array}$ \\
\hline $\begin{array}{l}\text { El Rio - Tebsa } 1 \\
110 \mathrm{kV}\end{array}$ & 138,40 & 101,99 & 106 & Unión $110 / 34,5 \mathrm{kV}$ \\
\hline 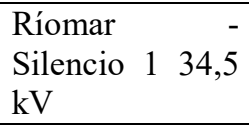 & 129,00 & 98,19 & 100 & $\begin{array}{llll}\text { Las } & \text { Flores } & & - \\
\text { Termoflores } & \text { I } & 1 & 110 \\
\text { kV } & & & \\
\end{array}$ \\
\hline $\begin{array}{lr}\text { Ríomar } & - \\
\text { Silencio } 2 & 34,5 \\
\mathrm{kV} & \\
\end{array}$ & 129,00 & 98,16 & 100 & 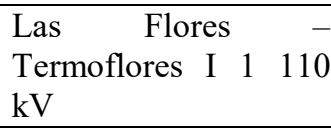 \\
\hline $\begin{array}{l}\text { El Rio - Tebsa } 1 \\
110 \mathrm{kV}\end{array}$ & 101,20 & 96,91 & 104 & $\begin{array}{llll}\text { Las } & \text { Flores } & & - \\
\text { Termoflores } & \text { I } & 1 & 110 \\
\mathrm{kV} & & & \\
\end{array}$ \\
\hline
\end{tabular}

As could be seen in TABLE 4, the failures that cause more chargeability are the contingencies from Tebsa - Unión $1110 \mathrm{kV}$, Unión 110/34,5 kV, and Las Flores - Termoflores I $1110 \mathrm{kV}$. This is consistent with the results reported by the AMPL model, showing an error in the calculations of the AMPL which is $10 \%$ lower compared to the error obtained in DigSILENT.

\section{CONCLUSIONS}

In spite of using the UPME expansion for STN and STR in the Atlántico region, 325 non-feasible cases are obtained from 1.800 in total without using BESS. The option of UPME batteries without protection schemes reduced this number to 217 non-feasible cases out of 1.860, compared to the XM and Quanta alternatives which did not offer the same effectiveness in this solution.

The batteries Las Flores 34,5 kV (1 p.u.) and Unión 34,5 kV (1 p.u) are the combinations that most appear, while the best combination is Location 3, which reaches 24 non-feasible cases out of 1.860 in total.

Comparing Location 3, which offers the lowest number of non-feasible cases, with a similar capacity of the UPME location, it's possible to find the same effectiveness in the solution in contingency cases of the STR Atlántico.

With AC power flow, the results of the AMPL+CPLEX model are compared with the electric results of DigSILENT Power Factory 2017, showing errors 10\% lower in the calculation of overloads. For the most critical contingencies evaluated in the AMPL program, no location of BESS with a capacity below to $340 \mathrm{MW}$ can solve the overload issues related to N-1 
contingencies. It is then necessary to carry out further studies including non-linear optimization and BESS locations in 110 $\mathrm{kV}$ networks for scenarios beyond 2019 in wind power and photovoltaic energy projects planned by the UPME.

\section{ACKNOWLEDGMENTS}

The authors thank INTERCOLOMBIA S.A. E.S.P and the Universidad Distrital Francisco Jose de Caldas for their collaboration in the development of this work.

\section{REFERENCES}

1. J. A. y M. S., «Battery Storage Systems in Electric Power Systems» June 18th, 2006. [En linea]. Available: https://pdfs.semanticscholar.org/ecdf/1b255ea762cbc3bc414062ea9fa772a36962.pdf. [Last access: January 10th, 2018].

2. IRENA (International Renewable Energy Agency), «BATTERY STORAGE FOR RENEWABLES: MARKET STATUS AND TECHNOLOGY OUTLOOK» January 2015.2 AOnline]. http://www.irena.org/documentdownloads/publications/irena_battery_storage_report_2015.pdf. [Last access: February 15th, $2018]$.

3. Fluence, «Fluence: A Siemens and AES Company Transform Your Network» January 2018. [Online]. Available: http://fluenceenergy.com/energy-storage-for-flexible-reliable-networks/. [Last access: January 10th, 2018].

4. UPME, «Plan de Expansión de Referencia Generación-Transmisión 2017-2031,» December 2017. [Online]. Available: http://www1.upme.gov.co/Documents/Energia\%20Electrica/Plan_GT_2017_2031_PREL.pdf. [Last access: December 26th 2017].

5. J. A, S. T. y A. T., «Battery Energy storage systems in transmission network expansion planning » March 32016.

6. [En linea]. Available: https://www.researchgate.net/publication/311970827_Battery_energy_storage_systems_in_transmission_network_expansion_ planning

7. K. D y J. O., «Battery energy storage technology for power systems- An overview» December 11th, 2008. [En linea]. Available: https://www.sciencedirect.com/science/article/abs/pii/S0378779608002642

8. Interconexión Eléctrica S.A. E.S.P. \& Quanta Technology, LLC, «Feasibility Study for Large Scale Energy Storage Systems, Task 3 Report: Battery Energy Storage System Technical» Quanta Technology, LLC, Raleigh, USA, 2017.

9. XM S.A. Gerencia Centro Nacional de Despacho, «Consideraciones y supuestos del modelo eléctrico del SIN en DigSILENT Power Factory del segundo semestre de 2017,» Dirección Planeación de la Operación, Medellín, July 2017.

10. INTERCOLOMBIA S.A. E.S.P., «GO-DO 1192, ESTUDIO ELÉCTRICO DE BATERÍAS ATLÁNTICO,» Dirección Operación, Medellin, 2017.

11. IEC, «Electrical Energy Storage» December 2011. [Online]. Available: http://www.iec.ch/whitepaper/pdf/iecWPenergystorage-LR-en.pdf. [Last access: February 10th, 2018].

12. J. I. S. M. I. Z. J. J. S. M. V. A. y P. E., «Energy Storage Technologies for Electric Applications» May 16th, 2017. [En linea]. Available: http://www.sc.ehu.es/sbweb/energias-renovables/temas/almacenamiento_l/almacenamiento_1.html\#rl. [Last access: February 7th, 2018]. 
13. INTERCONEXIÓN ELÉCTRICA S.A. E.S.P (ISA), «Perspectivas para la incorporación del Almacenamiento de Energía en el SIN Jornadas Almacenamiento CNO,» May 15th 2017. [Online]. Available: https://www.cno.org.co/sites/default/files/archivosAdjuntos/isa_almacenamientocno_20170515.pdf. [Last access: February 25th 2018]. 